\title{
LEARNING ENVIRONMENT OF MADRASAH EDUCATION IN THE ASIA'S LATIN CITY
}

\author{
Sheeva M. Yahcob-Saddalani \\ Faculty and Research Coordinator of Western Mindanao State University, Philippines. \\ (Email: shess@chemist.com)
}

Received date: 17-06-2019

Revised date: 08-07-2019

Accepted date: 19-07-2019

Published date: 15-09-2019

To cite this document: Yahcob-Saddalani, S. M. (2019). Learning Environment of Madrasah Education in The Asia's Latin City. International Journal of Education, Psychology and Counseling, 4 (32), 209-218.

DOI: $10.35631 /$ IJEPC.4320020

\begin{abstract}
The madrasah education is good in both the physical plant and facilities and the teaching and learning resources but only according to the minority views. This implies the existence of some problems in these identified areas of concern of madrasah education in Zamboanga City, Philippines. Thus, there is a need to address these issues of the physical plant and facilities and the teaching and learning resourcesfor more effective religious education in that culturally diverse community, commonly known as the Asia's Latin City.
\end{abstract}

Keywords: Madrasah Education, Physical Plant and Facilities, Teaching and Learning Resources

\section{Introduction}

No nation can ever claim of economic prosperity without investing much on human development (Saddalani, 2015). Madrasah education would have been an avenue for that desired moment of nation's success. In the Philippines, madrasah has been recognized as the single most important factor in the preservation of the Islamic faith and cultures (Boransing, 2014). Abdulkarim(2018) enumerated the factors hindering the development of Muslim education such as insufficient funding for teacher's salary and for institutional support program. Palis (2011), on the other hand, finds that the only area of Arabic Language and Islamic Values Education (ALIVE) program that needs enhancement is the curriculum. In spite of the weaknesses of the madrasah system, its educational thrust continues to thrive as traditional (weekend madrasah) and developmental (formal madrasah).

The struggling condition of Muslim education observed to have been aggravated by violence and terrorism incident involving the suicide bombers whose ideology perceived to be of Islamic inspired philosophy. Franklin D. Roosevelt (1941) believed that people anywhere in 
the world should enjoy freedom from fear. Madrasah education clamoured to be monitored so that the teaching it offers can be investigated. This study therefore investigated the learning environment of madrasah education in Zamboanga City, Philippines. Specifically, it sought to gain insightful commentaries on teaching and learning resources as well as on physical plant and facilities of madrasah education in that Asia's Latin City.

\section{Literature Review}

According to Sulu Oral Traditions, the first missionary by the name of Karim al- Makhdum came to the Philippines, preached Islam and introduced Islamic education (IE). Madrasah instituted for Muslim religious instruction. It offers courses for the study of Arabic language as well as Islamic beliefs and practices. Factors affecting the development of Islamic education in the Philippines is limited financial resources (Abdulkarim, 2018). Panda (2014) has similar prior findings.

The factors influencing the development of (IE) in the country are the Islamization and the institution of madrasah and government educational responses to the Moro struggle for selfdetermination. PD 1083, commonly known as the Code of Muslim Personal Laws of the Philippines, necessitates the exercise of Islamic Education. It gained strength from Ostrom's logic of public choice, a democratic administration (Tendero, 2001). The barrier, however, is the Secularism that has made Philippine educational system secular and highly centralized state. The Constitutional intervention is designed to determine the boundaries between the two institutions as observed in the principle of division of the religion and the state (Nolledo, 1987).

Brint (1998) acknowledged the important of institutional analysis as it shows how institutions are organized and how they respond to external factors such as educational policies and government educational bodies. Meso institutional analysis consists of three parts, namely: (1) analysis of practices related to the realization of the institution's purposes (2) analysis of the interests of the major actors in the institution and (3) analysis of the effects of the external environment on the workings of the institution. These frameworks provide trails to why institutions may not work, as they should. Said institutional analysis used as theoretical framework in this study.

\section{Methods}

The subject of this research is the madrasah (Islamic Institute) located in Zamboanga City that offers hierarchically structured education and sequential learning generally attuned with the Philippine formal education system. The study purposively chose the largest madaris in Zamboanga City because they are considered as the more established Islamic institutes in the city. From many of the madaris scattered throughout the Asia's Latin City, only four of them qualified to the purposive sampling research criterion.

The grand total sample of the four madaris is 96 respondents, 51 (53\%) are faculty and 45 $(47 \%)$ are students. The data for this study was obtained using a questionnaire-checklist and an interview using a structured interview questionnaire. The respondents evaluated the items in question form in terms of YES or NO. The data from the coded likert scale was evaluated using the statistical limits (Vanek, 2012 and Boone and Boone, 2012) with their equivalent 
verbal descriptions. A focus group discussion was conducted with the administrator of each madaris to further enlighten on the status and problems on physical plant and facilities and teaching and learning resources. For supplementary data, the four selected madaris were under observation of the researcher for ocular evaluation of the status and problems of the madaris in Zamboanga City.

\section{Findings and Discussion}

Table 1 presents the status of the madrasah in terms of its physical plant and facilities. Generally, there is almost an equal percentage of response as revealed by the grand mean percentage of $49.7 \%$ (Yes) and $50.3 \%$ (NO) for faculty respondents and $49.0 \%$ (Yes) and $51.0 \%$ (No) for student respondents. The affirmative answers generated a grand item means of 2.90 for faculty and 2.51 for student respondents, both with equivalent verbal description of "good". The affirmative response shows that the physical plant and facilities are neither superior nor inferior but with inclination to inferiority considering the negative response. While there are madaris which physical plant and facilities are at par with secular schools in the city, there are some madaris which physical plant and facilities can be considered inferior when compared to their secular counterparts.

Table 1: Status of Madrasah in Terms of The Physical Plant and Facilities

\begin{tabular}{|c|c|c|c|c|c|c|c|c|}
\hline \multirow{3}{*}{ Physical Plant and Facilities } & \multicolumn{4}{|c|}{ Faculty $(\mathrm{n}=51)$} & \multicolumn{4}{|c|}{ Student $(n=45)$} \\
\hline & \multirow{2}{*}{$\begin{array}{l}\text { NO } \\
(\%)\end{array}$} & \multicolumn{3}{|c|}{ YES } & \multirow{2}{*}{$\begin{array}{l}\text { NO } \\
(\%)\end{array}$} & \multicolumn{3}{|c|}{ YES } \\
\hline & & $\%$ & $\begin{array}{l}\text { Item } \\
\text { Mean } \\
\end{array}$ & VD & & $(\%)$ & $\begin{array}{l}\text { Item } \\
\text { Mean } \\
\end{array}$ & VD \\
\hline 1. Do you have a classroom? & 3.9 & 96.1 & 2.42 & $\begin{array}{l}\text { Very } \\
\text { good }\end{array}$ & 6.7 & 93.3 & 2.35 & $\begin{array}{l}\text { Very } \\
\text { good }\end{array}$ \\
\hline $\begin{array}{l}\text { 2. Does the classroom measure } 7 \\
\times 7 \text { as the standard design? }\end{array}$ & 52.9 & 47.1 & 2.36 & $\begin{array}{l}\text { Very } \\
\text { good }\end{array}$ & 48.9 & 51.1 & 2.45 & $\begin{array}{l}\text { Very } \\
\text { good }\end{array}$ \\
\hline $\begin{array}{l}\text { 3. Does your classroom have the } \\
\text { following features: } \\
3.1 \text { cemented floor? }\end{array}$ & 5.9 & 94.1 & 2.60 & Good & 13.3 & 86.7 & 2.38 & $\begin{array}{l}\text { Very } \\
\text { good }\end{array}$ \\
\hline $\begin{array}{l}\text { 3.2. smooth finish (plastered) } \\
\text { walls? }\end{array}$ & 15.7 & 84.3 & 2.70 & Good & 15.6 & 84.4 & 2.60 & Good \\
\hline 3.3. painted walls? & 21.6 & 78.4 & 2.83 & Good & 17.8 & 82.2 & 2.57 & Good \\
\hline 3.4. ceiling and roofing? & 0.0 & 100.0 & 2.84 & Good & 4.4 & 95.6 & 2.55 & Good \\
\hline 3.5. complete set of windows? & 15.7 & 84.3 & 2.93 & Good & 20.0 & 80.0 & 2.45 & $\begin{array}{l}\text { Very } \\
\text { good }\end{array}$ \\
\hline 3.6. two entrances with doors? & 58.8 & 41.2 & 2.84 & Good & 60.0 & 40.0 & 2.90 & Good \\
\hline $\begin{array}{l}\text { 3.7. complete electrical wires } \\
\text { and fixtures? }\end{array}$ & 13.7 & 86.3 & 2.97 & Good & 26.7 & 73.3 & 2.88 & Good \\
\hline 3.8. blackboard? & 0.0 & 100.0 & 2.45 & $\begin{array}{l}\text { Very } \\
\text { good }\end{array}$ & 2.2 & 97.8 & 2.47 & $\begin{array}{l}\text { Very } \\
\text { good }\end{array}$ \\
\hline $\begin{array}{l}\text { 4. Do you have a 1:45 ratio of } \\
\text { classroom to pupil? }\end{array}$ & 49.0 & 51.0 & 2.69 & Good & 42.2 & 57.8 & 2.49 & $\begin{array}{l}\text { Very } \\
\text { good }\end{array}$ \\
\hline
\end{tabular}




\begin{tabular}{|c|c|c|c|c|c|c|c|c|}
\hline $\begin{array}{l}\text { 5. Do you have a periodic } \\
\text { assessment of the classroom for } \\
\text { the following purposes: } \\
\text { 5.1. number of classrooms } \\
\text { needing repair? } \\
\text { 5.2. number of new classrooms } \\
\text { to be constructed? }\end{array}$ & $\begin{array}{l}19.6 \\
45.1\end{array}$ & $\begin{array}{l}80.4 \\
54.9\end{array}$ & $\begin{array}{l}3.04 \\
3.35\end{array}$ & $\begin{array}{l}\text { Good } \\
\text { Good }\end{array}$ & $\begin{array}{l}37.8 \\
44.4\end{array}$ & $\begin{array}{l}62.2 \\
55.6\end{array}$ & $\begin{array}{l}2.97 \\
2.78\end{array}$ & $\begin{array}{l}\text { Good } \\
\text { Good }\end{array}$ \\
\hline $\begin{array}{l}\text { 6. Does the school have the } \\
\text { following existing school } \\
\text { facilities: } \\
\text { 6.1. Library? } \\
\text { 6.2. Science laboratory? } \\
\text { 6.3. Clinic? }\end{array}$ & $\begin{array}{c}58.8 \\
100.0 \\
98.0\end{array}$ & $\begin{array}{r}41.2 \\
0.0 \\
2.0\end{array}$ & $\begin{array}{l}3.03 \\
\text { none } \\
3.50\end{array}$ & $\begin{array}{c}\text { Good } \\
\text { none } \\
\text { Fair }\end{array}$ & $\begin{array}{c}51.1 \\
100.0 \\
88.9\end{array}$ & $\begin{array}{c}48.9 \\
0.0 \\
11.1\end{array}$ & $\begin{array}{l}2.53 \\
\text { none } \\
2.97\end{array}$ & $\begin{array}{l}\text { Good } \\
\text { none } \\
\text { Good }\end{array}$ \\
\hline $\begin{array}{l}\text { 7. Do these facilities have } \\
\text { electricity to give adequate } \\
\text { lighting? }\end{array}$ & 49.0 & 51.0 & 2.88 & Good & 15.6 & 84.4 & 2.90 & Good \\
\hline $\begin{array}{l}\text { 8. Do your students have access to } \\
\text { potable water? }\end{array}$ & 31.4 & 68.6 & 2.70 & Good & 26.7 & 73.3 & 2.40 & $\begin{array}{l}\text { Very } \\
\text { good }\end{array}$ \\
\hline $\begin{array}{l}\text { 9. Is your source of water supply } \\
\text { generated by the following } \\
\text { 9.1. open well? }\end{array}$ & 90.2 & 9.8 & 2.96 & Good & 100.0 & 0.0 & none & none \\
\hline 9.2. deep well? & 78.4 & 21.6 & 3.06 & Good & 91.1 & 8.9 & 3.03 & Good \\
\hline 9.3. water main? & 25.5 & 74.5 & 2.65 & Good & 24.4 & 75.6 & 2.53 & Good \\
\hline 9.4. communal well? & 96.1 & 3.9 & 4.62 & Poor & 100.0 & 0.0 & none & none \\
\hline 9.5. spring? & 100.0 & 0.0 & $\mathrm{n} / \mathrm{a}$ & none & 100.0 & 0.0 & none & none \\
\hline 9.6. pumped $v$ & 64.7 & 35.3 & 2.44 & $\begin{array}{l}\text { Very } \\
\text { good }\end{array}$ & 84.4 & 15.6 & 1.98 & $\begin{array}{l}\text { Very } \\
\text { good }\end{array}$ \\
\hline 9.7. piped water? & 27.5 & 72.5 & 2.52 & Good & 17.8 & 82.2 & 2.65 & Good \\
\hline 9.8. dam? & 94.1 & 5.9 & 3.56 & Fair & 95.6 & 4.4 & 2.72 & Good \\
\hline 9.9. reservoir? & 74.5 & 25.5 & 2.71 & Good & 88.9 & 11.1 & 2.79 & Good \\
\hline $\begin{array}{l}\text { 10. Does your school have the } \\
\text { following community } \\
\text { facilities? } \\
\text { 10.1. Health facilities where } \\
\text { basic health services are } \\
\text { made available to people of } \\
\text { the community? } \\
\text { 10.2. Sports facilities where } \\
\text { community members can } \\
\text { engage in sports, games or } \\
\text { other activities that promote } \\
\text { their physical } \\
\text { development? }\end{array}$ & 52.9 & $\begin{array}{l}3.9 \\
47.1\end{array}$ & 2.05 & $\begin{array}{l}\text { Very } \\
\text { good } \\
\text { Fair }\end{array}$ & $\begin{array}{l}95.6 \\
44.4\end{array}$ & $\begin{array}{r}4.4 \\
55.6\end{array}$ & $\begin{array}{l}3.64 \\
3.47\end{array}$ & $\begin{array}{l}\text { Fair } \\
\text { Good }\end{array}$ \\
\hline $\begin{array}{l}\text { 11. Do you have a community } \\
\text { learning centers and training } \\
\text { centers for out-of-school youth }\end{array}$ & 68.6 & 31.4 & 2.87 & Good & 64.4 & 35.6 & 2.72 & Good \\
\hline
\end{tabular}




\begin{tabular}{|c|c|c|c|c|c|c|c|c|}
\hline and adults? & & & & & & & & \\
\hline Grand Mean & 50.3 & 49.7 & 2.90 & Good & 51.0 & 49.0 & 2.51 & Good \\
\hline
\end{tabular}

Legend: Rating Scale for Verbal Description (VD)

1.00-1.49 - Excellent 1.50-2.49 - Very Good 2.50-3.49 - Good 3.50-4.49 - Fair $\quad 4.50$ - 5.00 - Poor

The four madaris have classrooms according to $96.1 \%$ of the faculty and $93.3 \%$ of the student respondents, both with verbal description of "very good" based on their item means of 2.42 (faculty) and 2.35 (students). However, most of these classrooms do not measure 7 x 7 following the standard design. It is without two entrance doors following the highest rating for NO (58.8\% of faculty and $60.0 \%$ of student respondents). It is with cemented floor ( $94.1 \%$ of faculty and $86.7 \%$ of student respondents), smooth finish (plastered) walls (84.3\% of faculty and $84.4 \%$ of student respondents), painted walls (78.4\% of faculty and $82.2 \%$ of student respondents), ceiling and roofing (100.0\% of faculty and $95.6 \%$ of student respondents), complete set of windows (84.3\% of faculty and $80.0 \%$ of student respondents), complete electrical wires and fixtures (86.3\% of faculty and $73.3 \%$ of student respondents) and blackboard (100.0\% of faculty and $97.8 \%$ of student respondents). All are with resulted verbal description of "good" according to both groups of respondents, except for the blackboard which has "very good" verbal description.

The standard classroom to pupil ratio is $1: 45$. When asked of this ratio, the answer of both groups of respondents resulted to almost similar response with $49.0 \%$ of faculty and $42.2 \%$ of student respondents answered No and $51.0 \%$ of faculty and $57.8 \%$ of student respondents answered Yes. In the interview with administrators, each of their classrooms is good for 30 students but the attendance varies depending on the level of madrasah education. The higher the level, the lower is the numbers of students are expected.

There is a periodic assessment of the classroom as far as repair is concerned as perceived by $80.4 \%$ of the faculty and $62.2 \%$ of the student respondents, both with verbal description of "good". With respect to the number of new classrooms to be constructed, there is almost equal equation for No (45.1\% of faculty and $44.4 \%$ of student respondents) and YES (54.9\% of faculty and $55.6 \%$ of student respondents). The results will pave the way for improvement on classrooms, either through repair (which is most likely) or construction (which is a possibility). Whoever is capable is welcome to partake for madrasah.

There is almost similar response of NO (58.8\% of faculty and $51.1 \%$ of student respondents) and Yes (41.2\% of faculty and $48.9 \%$ of student respondents) when these respondents were asked of the existence of the library. It boils down to scarcity of resources when planning of place for a library with adequate lighting. As per observation, the books are just filed in one office occupied by the faculty and the school director. Majority of the faculty and the student respondents do not consider it as their library. There is no science laboratory and clinic as well.

The students have access to potable water as perceived by $68.6 \%$ of faculty and $73.3 \%$ of student respondents. The source of this potable water is from water main $(74.5 \%$ of faculty and $75.6 \%$ of student respondents) and from piped water (72.5\% of faculty and $82.2 \%$ for student respondents). One of the madaris has pumped water and deep well and an 
international donor as imprinted therein sponsored its construction. Two of the madaris have reservoir as per observation.

The madrasah does not have a health facility $(96.1 \%$ of faculty and $95.6 \%$ of student respondents) but it has a "fair" sport facility (47.1\% of faculty and $55.6 \%$ of student respondents) attested by the existence of functional basketball court. Roughly about $68 \%$ of the faculty and $64 \%$ of the student respondents perceived that the madrasah does not have a community learning centers and training centers for out-of-school youth and adults. Each madrasah, however, has a program called "Hafidz" intended for students who want to understand and memorize the Qur'an. This program requires the students to stay in the campus for a period of two years or more. In the interview with administrator, he relates that some parents choose to enrol their children in the madrasah program after they have been seen to be disinterested in secular schools. Hence, learning and training centers for out-ofschool youth somehow exists as also attested by the minority of the respondents.

The above findings indicate that the physical plant and facilities of the madrasah do not have some of the features of the secular school such as science laboratory, clinic, the specified classroom measurement, and classroom to pupil ratio. The madrasah in Zamboanga City is known to co-exist with the secular schools in the city, testament of the fact that education is a mean to build a culture of peace (UN, 2013).

Table 2 presents the status of the madrasah in terms of its teaching and learning resources. The grand means of the percentage of NO answer $(70.4 \%$ of faculty and $59.0 \%$ of student respondents) are higher than the percentage of YES answer $(29.6 \%$ of faculty and $41.0 \%$ of student respondents). The grand item means of affirmative response are 2.82 (faculty) and 2.68 (students), both with verbal description equivalent to "good".

Table 2: Status of Madrasah In Terms of The Teaching and Learning Resources

\begin{tabular}{|c|c|c|c|c|c|c|c|c|}
\hline \multirow{3}{*}{$\begin{array}{c}\text { Teaching and Learning } \\
\text { Resources }\end{array}$} & \multicolumn{4}{|c|}{ Faculty $(n=51)$} & \multicolumn{4}{|c|}{ Student $(n=45)$} \\
\hline & \multirow{2}{*}{$\begin{array}{l}\text { NO } \\
(\%)\end{array}$} & \multicolumn{3}{|c|}{ YES } & \multirow{2}{*}{$\begin{array}{l}\text { NO } \\
(\%)\end{array}$} & \multicolumn{3}{|c|}{ YES } \\
\hline & & $\%$ & $\begin{array}{l}\text { Item } \\
\text { Mean }\end{array}$ & VD & & $\%$ & $\begin{array}{r}\text { Item } \\
\text { Mean }\end{array}$ & VD \\
\hline $\begin{array}{l}\text { 1.Do you have the following } \\
\text { textbooks for the following } \\
\text { secular subjects: }\end{array}$ & & & & & & $\begin{array}{c}24 . \\
4\end{array}$ & & \\
\hline 1.1. English? & 94.1 & 5.9 & 2.71 & Good & 75.6 & 17. & 3.03 & Good \\
\hline 1.2. Science? & 94.1 & 5.9 & 3.22 & Good & 82.2 & 8 & 2.75 & Good \\
\hline 1.3. Math? & 90.2 & 9.8 & 2.65 & Good & 80.0 & 20. & 3.00 & Good \\
\hline 1.4. Makabayan & 96.1 & 3.9 & 3.59 & Fair & 84.4 & $\begin{array}{c}0 \\
15 . \\
6\end{array}$ & 2.95 & Good \\
\hline $\begin{array}{l}\text { Is the textbook to pupil ration } 1: 1 \\
\text { per subject? }\end{array}$ & 86.3 & 13.7 & 2.34 & $\begin{array}{l}\text { Very } \\
\text { good }\end{array}$ & 71.1 & 28.9 & 2.38 & $\begin{array}{l}\text { Very } \\
\text { good }\end{array}$ \\
\hline $\begin{array}{l}\text { 3. Are there available } \\
\text { supplementary reading } \\
\text { materials? }\end{array}$ & 41.2 & 58.8 & 2.60 & Good & 35.6 & 64.4 & 2.90 & Good \\
\hline
\end{tabular}




\begin{tabular}{|c|c|c|c|c|c|c|c|c|}
\hline $\begin{array}{l}\text { 4. Are there available teaching } \\
\text { devices and visual aids? }\end{array}$ & 74.5 & 25.5 & 3.76 & Fair & 48.9 & 51.1 & 3.23 & Good \\
\hline $\begin{array}{l}\text { 5. Do the teachers hold a regular } \\
\text { item/plantilla of position? }\end{array}$ & 66.7 & 33.3 & 2.73 & Good & 42.2 & 57.8 & 3.08 & Good \\
\hline $\begin{array}{l}\text { 6. Do you have teachers who are } \\
\text { on temporary } \\
\text { position/appointment? }\end{array}$ & 37.7 & 62.7 & 3.22 & Good & 22.2 & 77.8 & 2.97 & Good \\
\hline $\begin{array}{l}\text { 7. Does your school have a } 1: 45 \\
\text { ratio of teacher to pupil? }\end{array}$ & 68.6 & 31.4 & 2.74 & Good & 55.6 & 44.4 & 2.65 & Good \\
\hline $\begin{array}{l}\text { 8. Do you have trained teachers } \\
\text { for the following subjects: } \\
\text { 8.1. English? } \\
\text { 8.2. Science? } \\
\text { 8.3. Math? } \\
\text { 8.4. Madrasah subjects? }\end{array}$ & $\begin{array}{c}80.4 \\
82.4 \\
78.4 \\
7.8\end{array}$ & $\begin{array}{l}19.6 \\
17.6 \\
21.6 \\
92.2\end{array}$ & $\begin{array}{l}2.81 \\
3.13 \\
2.73 \\
1.62\end{array}$ & $\begin{array}{l}\text { Good } \\
\text { Good } \\
\text { Good } \\
\text { Very } \\
\text { good }\end{array}$ & $\begin{array}{c}77.8 \\
77.8 \\
77.8 \\
0.0\end{array}$ & $\begin{array}{c}22.2 \\
22.2 \\
22.2 \\
100 . \\
0 \\
\end{array}$ & $\begin{array}{l}2.30 \\
2.43 \\
2.43 \\
1.71\end{array}$ & $\begin{array}{l}\text { Very } \\
\text { good } \\
\text { Very } \\
\text { good } \\
\text { Very } \\
\text { good } \\
\text { Very } \\
\text { good }\end{array}$ \\
\hline $\begin{array}{l}\text { 9. Did your teacher complete a } \\
\text { regular, on-going professional } \\
\text { development program to } \\
\text { enhance his/her skills, } \\
\text { knowledge or overall ability to } \\
\text { deliver quality alternative } \\
\text { system (ALS) program? }\end{array}$ & 56.9 & 43.1 & 2.73 & Good & 53.3 & 46.7 & 2.38 & $\begin{array}{l}\text { Very } \\
\text { good }\end{array}$ \\
\hline Grand Mean & 70.4 & 29.6 & 2.84 & Good & 59.0 & $\begin{aligned} & 41 . \\
& 0\end{aligned}$ & 2.68 & ood \\
\hline
\end{tabular}

Legend: Rating Scale for Verbal Description (VD)

1.00-1.49 - Excellent $\quad$ 1.50-2.49 - Very Good $\quad 2.50-3.49$ - Good $\quad 3.50-4.49$ - Fair $\quad 4.50$ - 5.00 Poor

Majority of the respondents noted the absence of textbooks for the secular subjects, namely: English, Science, Math, and Makabayan. Minority of the respondents noted the presence of the subjects mention earlier: 24.4\% (English), 17.8\% (Science), 20.0\% (Math), and 15.6\% (Makabayan). The percentage of the minority response is attributed to the fact that one of the madaris is in its way to secular integration. In fact, they have begun their operation for preschool and grade school level.

There is no substantial evidence for 1:1 textbook to pupil ratio per subject as attested by $86.3 \%$ of faculty and $71.1 \%$ of student respondents. However, there are seemingly reasonable numbers of supplementary reading materials as indicated in the response of the respondents that tells of the availability of the said supplementary reading materials $(58.8 \%$ of faculty and $64.4 \%$ of student respondents). The $74.5 \%$ of the faculty respondents are convinced that they do not have teaching devices such as laptop, projector and visual aids. They have satisfied themselves with blackboard and chalk in their teaching engagements. Almost half of the student respondents would like to experience the usage of these advance teaching devices and visual aids to compliment the traditional method of blackboard and 
chalk. Both group of respondents agreed that the madrasah does not have a 1:45 teacher to pupil ratio (68.6\% of faculty and $55.6 \%$ of student respondents). The ratio is dependent on the level of madrasah education. Generally, the ratio is greater in lower grade (from grade 0 to grade 4) and less in higher grade (from grade 5 to college).

Faculty is trained for madrasah subjects as revealed by the affirmative response of $92.2 \%$ of faculty and $100.0 \%$ of student respondents. Faculty has knowledge on secular subjects as manifested in their educational backgrounds. But they have not trained further in the secular subjects (English, Science and Math) according to the respondents who answered mostly for No.

According to $66.7 \%$ of the faculty respondents, their positions are not on a regular item/plantilla. Specifically, they are on temporary position/appointment $(62.7 \%$ of the faculty respondents). The student respondents $(77.8 \%)$ have the same perception that their "guru" holds temporary position.

More than half of each respondent group (56.9\% of faculty and $53.3 \%$ of student respondents) believes that the faculty does not undergo trainings. In the interview with one of the directors of the madaris, however, in which he says that there were trainings sponsored by private entities before the Zamboanga Siege last September 9, 2013. There have been no invitations for faculty training yet received since then, he added.

From the data presented, it could be inferred that the madrasah has trained faculty for madrasah subjects. It is even regarded as its strength with faculty who are mostly graduates of foreign Islamic schools. However, its weakness lies with the teaching and learning resources based on a resulted grand mean of $70.4 \%$ of the faculty and $59.0 \%$ of the student respondents who answered for No.

The faculty and the student respondents have "good" evaluation in both the physical plant and facilities, and the teaching and learning resources, however of the minority views. The madrasah has been able to sustain its effort into a considerable extent amidst insufficiency in physical plant and facilities and teaching and learning resources. While there are madaris which physical plant and facilities are at par with the secular schools in the city, there are some which physical plant and facilities can be considered way below their secular counterparts. In general, the physical plant and facilities of the madrasah do not have some of the features of the secular school such as science laboratory, clinic, the specified classroom measurement, and classroom to pupil ratio. The madrasah has trained faculty for madrasah subjects. It is even regarded as its strength with faculty who are mostly graduates of foreign Islamic schools. However, its weakness lies with the teaching and learning resources based on a resulted grand mean of $70.4 \%$ of the faculty and $59.0 \%$ of the student respondents that answered it, No.

The physical plant and facilities of the four madaris are not within the Philippine specified standard classroom measurement of 7x7. In addition, neither of the science laboratory nor of the clinic and health facilities is tangibly in place. Amidst an indication of low salary for faculty, their religious devotion emerged to be the strongest motive in the discharge of their 
duties and responsibilities. As read in the Qur'an in Surah Ar-Rum 30 verse 47, “...To help the believers is incumbent upon us." It would be better, however, that these faculty members be accorded of regular item/plantilla of position pending the progress of any salary increase brought about by any potential changes in the financing structure of madrasah.

\section{Conclusion}

The madrasah education in the Asia's Latin City is "good" in both physical plant and facilities and teaching and learning resources but only according to the minority views. The areas that needed improvement according to the order of priority are physical plant and facilities, and teaching and learning resources. The madrasah has been able to sustain its effort into a considerable extent amidst manifested insufficiency in physical plant and facilities and teaching and learning resources. This is indicative of the Muslim community's strong desire to ensure that their children receive an Islamic education (IE).

These areas of concern of madrasah education would have been addressed through consideration of government grant, the latter is conditioned upon the imposition of the Philippine RBEC subjects (Republic of the Philippines, Department of Education, 2011). Thus, study on the madrasah curriculum needs to explore to address such issue of inclusion. Subsequent study on its administrative and financial management practice is of equal important to help established its own narratives of peace.

\section{References}

Abdulkarim, K. (2018). Evaluation on the Integration of Madaris Curriculum for Muslim Basic Education in Mindanao, Philippines. Ph.D. Universitas Muhammadiyah Yogyakarta, Indonesia.

Boone, H. and Boone, D. (2012). Analyzing Likert Data. Journal of Extension, [online] 50(2). Available at: http://www.joe.org [Accessed 12 Feb. 2015].

Boransing, M. (2014). Official Definition of Madrasah. [online] Muslim Mindanao for Journalists and other Communicators. Available at: http://www.muslimmindanao.ph/madrasa.html [Accessed 12 Feb. 2014].

Brint, S. (1998). Schools and Societies. United States: Pine Forge Press.

Nolledo, Jose N. (1987). The Constitution of the Republic of the Philippines explained: English-Filipino version. Manila, Philippines:National Book Store.

Palis, M.G. (2011). Madrasah Education in Davao City: Issues, Claims and Concerns. Thesis. College of Education-University of South eastern Philippines, Davao City.

Panda, A. (2014). Islamic Education: Problems and Development in Philippine Secular State. [online] Available at: http://wamyphil.com/36/islamic-education-problemsdevelopment-in-philippine-secular-state/. [Accessed 15 Jan. 2014].

Rasul, Jainal D. (2003). Commentaries and Jurisprudence: Muslim Code of the Philippines with Special Rules of Procedure in Shariah Courts. Quezon City: FedPil Publishing.

Republic of the Philippines, Department of Education. (2011). Amendment to DepEd Order No. 51, s. 2004. [online] Available at: http://www.deped.gov.ph [Accessed 10 Feb. 2014].

Roosevelt, Franklin D. State of Union address. [online] Available at: www.voicesofdemocracy.umd.edu/fdr-the-four-freedoms-speech-Text/ [Accessed 15 Jan 2015]. 
Saddalani, A. (2015). Madrasah in Zamboanga City: Status, Problem and Prospects for Peace. Dissertation. College of Teacher Education-Western Mindanao State University, Zamboanga City.

Tendero, A. (2001). Theory and Practice of Public Administration in the Philippines. Fiscal Administration Foundation, Philippines.

The Noble Qur-an. (n.d.). King Fahd Complex.

UN Documents. Declaration on a Culture of Peace. [online] Available at:www.undocuments.net/a53r243a.htm [Accessed 14 Dec 2014].

Vanek, C. (n.d.) (2015, February 20) Likert Scale-What is it? When to Use It? How to Analyze It? [online] Available at www.surveygizmo.com. [Accessed 20 Feb. 2015]. 